\title{
Oxidation of an Oil Rich in Docosahexaenoic Acid Compared to Linoleic Acid in Lactating Women
}

\author{
N. Fidler T. Sauerwald H. Demmelmair A. Pohl B. Koletzko \\ Division of Metabolic Disorders and Nutrition, Kinderklinik and Kinderpoliklinik, \\ Dr. von Haunersches Kinderspital, Ludwig Maximilians University, Munich, Germany
}

\section{Key Words}

Oxidation - Docosahexaenoic acid .

Linoleic acid $\cdot{ }^{13} \mathrm{C}$-labeled fatty acids .

Isotopic ratio mass spectrometry $\cdot$ Lactation

\begin{abstract}
Background: We studied the oxidation of an oil rich in docosahexaenoic acid (DHA; DHASCO ${ }^{\circledR}$ ) in lactating mothers receiving a dietary DHA supplement or a placebo. The results were compared with the oxidation of linoleic acid. Methods: Breast-feeding mothers received a dietary supplement (DHASCO; $200 \mathrm{mg}$ DHA/day, $\mathrm{n}=5$ ) or a placebo $(\mathrm{n}=5)$ for 14 days. Six weeks post partum all 10 mothers received a single dose of $2 \mathrm{mg} / \mathrm{kg}$ body weight uniformly ${ }^{13} \mathrm{C}$-labeled DHASCO. In a previously reported study 6 mothers received $1 \mathrm{mg} / \mathrm{kg}$ body weight uniformly ${ }^{13} \mathrm{C}$ labeled linoleic acid. Breath samples were collected over $48 \mathrm{~h}$ after tracer application.
\end{abstract}

The total $\mathrm{CO}_{2}$ production was measured by indirect calorimetry and the ${ }^{13} \mathrm{C}$ isotopic enrichment of labeled $\mathrm{CO}_{2}$ by isotopic ratio mass spectrometry. Results: The oxidation of ${ }^{13} \mathrm{C}$-labeled DHASCO in the supplemented and placebo groups was similar. Maximal ${ }^{13} \mathrm{C}$ enrichment was reached earlier in the group receiving ${ }^{13} \mathrm{C}$-DHASCO (median 1.0 vs. $3.0 \mathrm{~h}$ in the linoleic acid group). The cumulative ${ }^{13} \mathrm{C}$ recovery in breath was higher in the DHAS$\mathrm{CO}$ versus the linoleic acid group until $10 \mathrm{~h}$ after tracer application and comparable thereafter. Conclusions: The difference in oxidation of DHASCO versus linoleic acid after tracer ingestion might be partly due to a faster absorption and oxidation of shorter chain saturated fatty acids contained in DHASCO. The cumulative oxidation of DHASCO and linoleic acid 24 and $48 \mathrm{~h}$ after tracer ingestion is similar.

\footnotetext{
Copyright (C) 2000 S. Karger AG, Basel
}

\begin{tabular}{ll}
\hline KARGER & ( ) 2000 S. Karger AG, Basel \\
Fax +4161306 1234 $34-6807 / 99 / 0436-0339 \$ 17.50 / 0$ \\
$\begin{array}{l}\text { E-Mail karger@karger.ch } \\
\text { www.karger.com }\end{array}$ & $\begin{array}{l}\text { Accessible online at: } \\
\text { www.karger.com/journals/anm }\end{array}$
\end{tabular}

Berthold Koletzko, MD, Division of Metabolic Diseases and Nutrition Kinderklinik and Kinderpoliklinik, Dr. von Haunersches Kinderspital Ludwig Maximilians University, Lindwurmstrasse 4

D-80337 München (Germany), Fax +49 8951603336 E-Mail Berthold.Koletzko@kk-i.med.uni-muenchen.de 


\section{Introduction}

The supply of essential fatty acids and long-chain polyunsaturated fatty acids (LCP) is important for normal growth and development of infants. Their contents in human milk depend on maternal nutrition, utilization, and composition of depot fats and endogenous LCP synthesis from precursors [13]. Essential fatty acids and LCP may also be used as an energy source and thus be oxidized to $\mathrm{CO}_{2}$. Methods for measuring the in vivo oxidation of substrates labeled with the nonradioactive isotope ${ }^{13} \mathrm{C}$ have been increasingly used for diagnostic and research purposes [4-6]. Small excesses of exogenous ${ }^{13} \mathrm{CO}_{2}$ arising from oxidation of the labeled substrate can be measured by sensitive mass spectrometry techniques $[5,6]$.

The first objective of this study was to investigate the oxidation of an orally applied ${ }^{13} \mathrm{C}$-labeled oil rich in docosahexaenoic acid (DHA; DHASCO ${ }^{\circledR}$, Martek Biosciences, Columbia, Md., USA) in a group of lactating mothers supplemented either with DHA or a placebo oil. The second objective was to compare the oxidation of this fatty acid mixture containing about $40 \%$ DHA with the oxidation of a single polyunsaturated fatty acid (linoleic acid) in lactation.

\section{Subjects and Methods}

Ten healthy breast-feeding mothers were recruited after term delivery at the Department of Gynecology and Obstetrics, University of Munich. The study was approved by the Ethical Committee of the Medical Faculty of the University of Munich, and written consent was obtained from the participating women.

The women were $31 \pm(\mathrm{SD}) 5$ years old and had a weight of $71.4 \pm 4.6 \mathrm{~kg}$ (at 4 weeks post partum) and a height of $170 \pm 6 \mathrm{~cm}$. All were consuming omnivorous diets which were assessed by 7-day weighted dietary protocols. At 4 weeks post partum (study day 0 ), they were randomly and blindly assigned to receive either a
Table 1. Fatty acid composition (w\%) of the capsules with the dietary supplement DHASCO oil, the ${ }^{13} \mathrm{C}$ labeled DHASCO oil, and the placebo capsules containing a 1:1 mixture of corn and soy oils

\begin{tabular}{|c|c|c|c|}
\hline Fatty acid & $\begin{array}{l}\text { DHASCO } \\
\text { capsules }^{\text {a }}\end{array}$ & $\begin{array}{l}{ }^{13} \mathrm{C} \text {-labeled } \\
\text { DHASCO }\end{array}$ & $\begin{array}{l}\text { Placebo } \\
\text { capsules }^{\text {b }}\end{array}$ \\
\hline C8:0 & - & $0.0-0.3$ & - \\
\hline C10:0 & - & $1.1-1.8$ & - \\
\hline $\mathrm{C} 12: 0$ & 5.4 & $7.8-9.3$ & - \\
\hline C14:0 & 19.40 & $18.1-19.6$ & - \\
\hline C16:0 & 17.5 & $9.0-13.2$ & 11.0 \\
\hline C18:0 & 0.4 & $0.0-0.3$ & 3.0 \\
\hline C20:0 & - & 0.1 & 0.4 \\
\hline C16:1n-7 & 1.7 & $0.9-1.0$ & - \\
\hline C18:1n-9 & 9.5 & $5.1-7.4$ & 23.3 \\
\hline C20:1n-9 & - & $0.0-0.3$ & 0.3 \\
\hline C18:2n-6 & 0.6 & - & 56.7 \\
\hline C18:3n-3 & - & - & 4.1 \\
\hline$C 22: 5 n-3$ & 0.3 & $0.2-0.4$ & - \\
\hline$C 22: 6 n-3$ & 45.1 & $49.3-55.4$ & - \\
\hline C24:1n-9 & - & - & - \\
\hline
\end{tabular}

a Analysis in our laboratory (analysis of ${ }^{13} \mathrm{C}$ tracer represents the range from three different lots).

b Compositional data provided by the manufacturer.

dietary supplement rich in DHA (200 mg DHA/day from DHASCO capsules) or a placebo oil for 14 days. The mothers were asked not to eat fish (rich in n-3 LCP) during the 2-week supplementation period. Further, they were asked not to eat corn-based products the day before tracer application because of an elevated ${ }^{13} \mathrm{C}$ content. At 6 weeks post partum mothers from both groups received with their breakfast a single dose of $2 \mathrm{mg} / \mathrm{kg}$ of uniformly ${ }^{13} \mathrm{C}$-labeled DHASCO oil (57.1-65.7\% ${ }^{13} \mathrm{C}$ enrichment). The fatty acid compositions of the DHASCO and placebo capsules as well as the tracer are shown in table 1 . In a previously published comparable study [1], 6 breast-feeding mothers (age $31 \pm 3$ years, weight $68.17 \pm 8.2 \mathrm{~kg}$, height $167 \pm$ $3 \mathrm{~cm}$; mean $\pm \mathrm{SD}$ ) received a single dose of uniformly ${ }^{13} \mathrm{C}$-labeled linoleic acid $\left(\sim 98 \%{ }^{13} \mathrm{C}\right.$ labeling; Martek Biosciences) at 6 weeks post partum.

Exhaled breath samples were collected into 1-liter breath bags. An aliquot of $11 \mathrm{ml}$ was transferred into evacuated glass tubes (Labco, Manchester, UK) and 
stored until measurement of the ${ }^{13} \mathrm{C}$ content of the $\mathrm{CO}_{2}$. Immediately before tracer application a breath sample was taken in triplicate in order to measure baseline ${ }^{13} \mathrm{C}$ enrichment of $\mathrm{CO}_{2}$. Further samples were collected 30 min and 1, 2, 3, 4, 5, 6, 7, 8, 9, 10, 12, 24, 36 , and $48 \mathrm{~h}$ after tracer administration. The total $\mathrm{CO}_{2}$ production was measured by indirect calorimetry twice in each woman from 30 min preprandial until 30 min postprandial (Deltatrac ${ }^{\circledR}$ II MBM-200; Hoyer, Bremen, Germany). The ${ }^{13} \mathrm{C}$ enrichments of breath $\mathrm{CO}_{2}$ were measured in duplicate by isotopic ratio mass spectrometry (Delta S; Finnigan MAT, Bremen). Carbon isotope ratios were expressed as $\delta{ }^{13} \mathrm{C}$ values (\%) versus the Pee Dee Belemnite standard. The oxidation rates over $48 \mathrm{~h}$ were calculated as described elsewhere [1].

Statistical differences between the DHA-supplemented group and the placebo group as well as between the groups combined (supplemented and placebo groups; $\mathrm{n}=10$ ) and the group given ${ }^{13} \mathrm{C}$ linoleic acid were assessed by a nonparametric test (Mann-Whitney, Monte Carlo) using the Stastical Package for the Social Sciences (version 8.0; SPSS, Chicago, Ill., USA). This test was chosen due to the relatively small number of subjects per group. The significance level was set at $\mathrm{p}<0.05$, and the results are presented as median and interquartile range (IQR).

\section{Results}

The times of peak ${ }^{13} \mathrm{C}$ enrichment in breath $\mathrm{CO}_{2}$ (delta over baseline, $\mathrm{DOB}$ ) of the DHA-supplemented group and the placebo group were at $1 \mathrm{~h}(1.0-1.0$; median and IQR) and at $2 \mathrm{~h}$ (1.0-3.3), respectively (table 2). Forty-eight hours after tracer application ${ }^{13} \mathrm{C}$ enrichment in both groups had almost returned to baseline values [DOB $0.21 \% 0(0.04-$ $0.59)]$. Because of the nearly identical kinetics of the supplemented and the placebo group, both were combined for comparison with the linoleic acid group.

Time of peak ${ }^{13} \mathrm{C}$ enrichment in the combined group was at $1 \mathrm{~h}(1.0-2.0)$ after tracer application which was about $3 \mathrm{~h}$ earlier than in the linoleic acid group [3.5 h (3.0-4.0); $\mathrm{p}=$ 0.003].

Oxidation of DHA in Lactating Women
The percentage of the dose of tracer ${ }^{13} \mathrm{C}$ exhaled in $\mathrm{CO}_{2}$ per hour (percent dose recovery; PDR/h) tended to be slightly higher during the first $2 \mathrm{~h}$ after tracer application in the DHA-supplemented versus the placebo group which was not significantly different due to large interindividual differences (fig. 1). From 3 to $48 \mathrm{~h}$ after tracer application, the tracer oxidation did not differ between the supplemented and the placebo groups.

A comparison of the combined group and the linoleic acid group showed a severalfold higher PDR/h in the group receiving labeled DHASCO during the first $4 \mathrm{~h}$ after tracer application: 18-fold higher at $1 \mathrm{~h}$ after tracer ingestion, 7-fold higher at $2 \mathrm{~h}, 3.4$-fold higher at $3 \mathrm{~h}$, and 1.6-fold higher at $4 \mathrm{~h}$ (fig. 2). At the later time points, 5-24 $\mathrm{h}$ after tracer application, there were no significant differences between the combined and the linoleic acid group. At 30 and $48 \mathrm{~h}$ after tracer application, the PDR/h in the linoleic acid group versus the combined group was higher [ $30 \mathrm{~h}: 0.22$ $(0.17-0.28)$ vs. $0.13(0.08-0.15), \mathrm{p}=0.003$; $48 \mathrm{~h}: 0.20(0.12-0.25)$ vs. $0.05(0.03-0.08)$, $\mathrm{p}=0.026$; see figure 2 ).

The cumulative PDR/h of tracer doses in breath tended to be higher in the DHA-supplemented group than in the placebo group during the first $2 \mathrm{~h}$ after tracer application. This difference was significant only at $1 \mathrm{~h}$ after the tracer application [1.61\% (1.38$1.77)$ in the supplemented vs. $0.76 \%(0.40-$ 1.15 ) in the placebo group, $p=0.033$ ].

The cumulative recovery of ${ }^{13} \mathrm{C}$ in the combined group at $1 \mathrm{~h}$ after tracer ingestion was 10.7-fold higher than in the linoleic acid group (1.28 vs. 0.12). This tendency was observed during the first $10 \mathrm{~h}$ after tracer application. From 24 to $48 \mathrm{~h}$ after tracer application, the cumulative recovery of DHASCO and linoleic acid was very similar and reached about $15 \%$ of the ingested doses (fig. 3).

Ann Nutr Metab 1999;43:339-345 341 


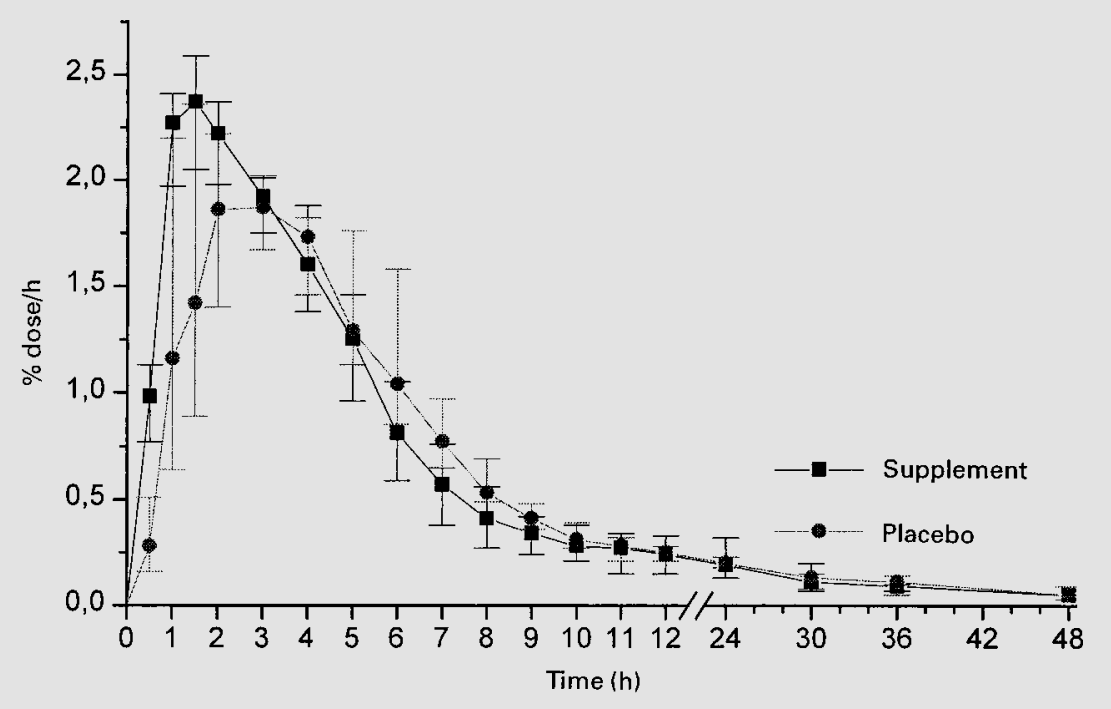

1

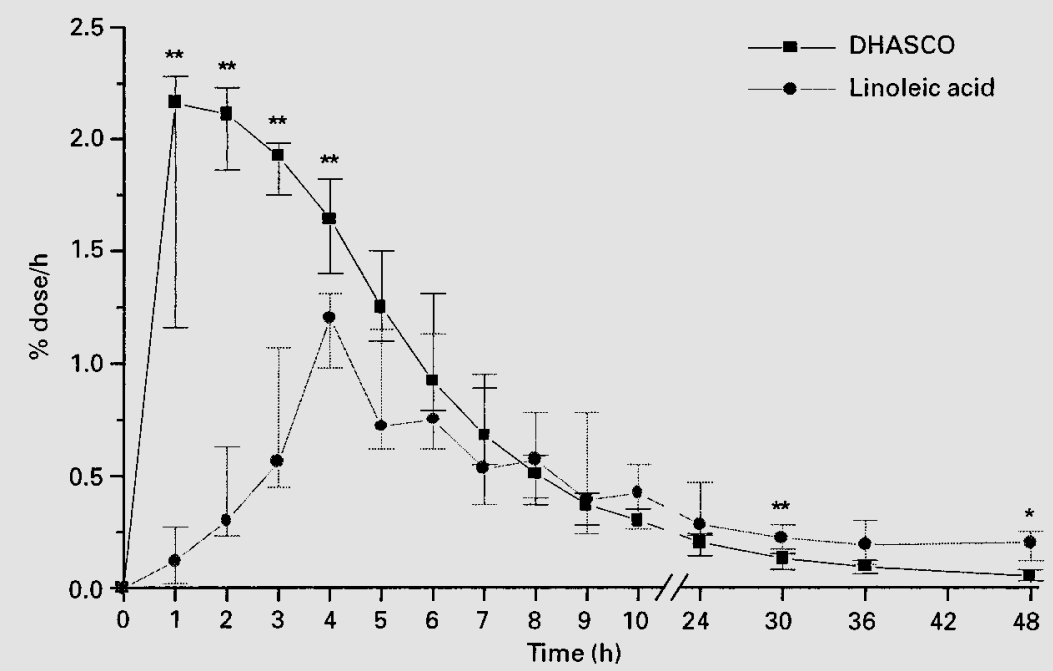

2

Fig. 1. Time course of ${ }^{13} \mathrm{C}$ in breath $\mathrm{CO}_{2}$ in breast-feeding mothers receiving DHA supplementation $(\mathrm{n}=5)$ or a placebo $(\mathrm{n}=5)$ after oral application of $2 \mathrm{mg} / \mathrm{kg}$ body weight of $\mathrm{U}-{ }^{13} \mathrm{C}$-labeled DHASCO, expressed as percentage of tracer dose ingested per hour (PDR/h). Median and IQR.

Fig. 2. Time course of ${ }^{13} \mathrm{C}$ in breath $\mathrm{CO}_{2}$ in breast-feeding mothers after oral tracer application of ${ }^{13} \mathrm{C}$-DHASCO $(\mathrm{n}=10)$ or ${ }^{13} \mathrm{C}$-linoleic acid $(\mathrm{n}=6)[1]$. Median and IQR. ${ }^{*} \mathrm{p}<0.05$; $* * \mathrm{p}<0.01$. 


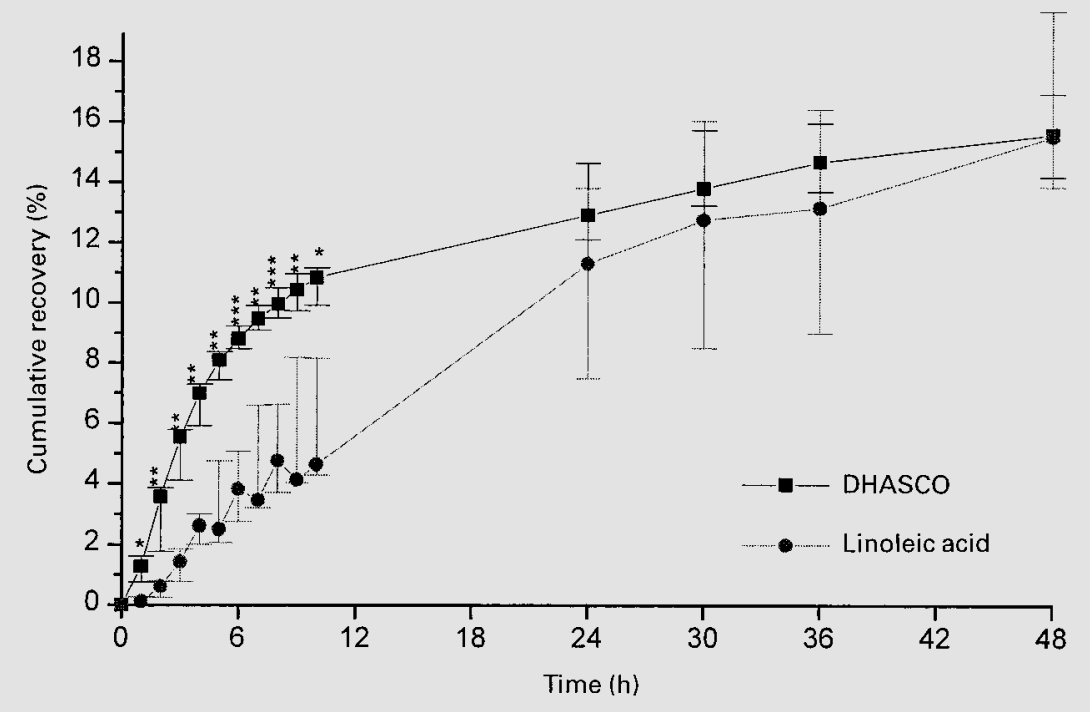

Fig. 3. Time course of cumulative recovery of ${ }^{13} \mathrm{C}$ in breath $\mathrm{CO}_{2}$ in breast-feeding mothers after oral tracer application of ${ }^{13} \mathrm{C}-\mathrm{DHASCO}(\mathrm{n}=10)$ or ${ }^{13} \mathrm{C}$-linoleic acid $(\mathrm{n}=6)$ [1]. Median and IQR. ${ }^{*} \mathrm{p}<0.05 ; * * \mathrm{p}<0.01 ; * * * \mathrm{p}<0.001$.

Table 2. Time point of $\delta^{13} \mathrm{C}$ peak and peak $\delta^{13} \mathrm{C}$ values $(\% 0)$ in breath $\mathrm{CO}_{2}$ of lactating women after oral administration of ${ }^{13} \mathrm{C}$-DHASCO and ${ }^{13} \mathrm{C}$-linoleic acid [1] at 6 weeks post partum

\begin{tabular}{|c|c|c|}
\hline $\begin{array}{l}\text { Supplement DHASCO } \\
{ }^{13} \mathrm{C}-\mathrm{DHASCO} \\
(\mathrm{n}=5)\end{array}$ & $\begin{array}{l}\text { Placebo } \\
{ }^{13} \mathrm{C}-\mathrm{DHASCO} \\
(\mathrm{n}=5)\end{array}$ & $\begin{array}{l}\text { Regular diet } \\
{ }^{13} \mathrm{C}-\text { linoleic acid } \\
(\mathrm{n}=6)\end{array}$ \\
\hline subject No. h & subject No. $\mathrm{h}$ & subject No. h \\
\hline
\end{tabular}

\begin{tabular}{lcrccc}
\hline \multicolumn{7}{l}{ Time point of $\delta^{13}$ C peak ( after administration) } \\
1 & 1 & 6 & 1 & 11 & 3 \\
2 & 1 & 7 & 1 & 12 & 4 \\
3 & 1 & 8 & 2 & 13 & 5 \\
4 & 1 & 9 & 3 & 14 & 3 \\
5 & 1 & 10 & 4 & 15 & 3 \\
\hline Peak $\delta^{13}$ C value, \%o & & & & \\
1 & 22.47 & 6 & 22.47 & 11 & 9.95 \\
2 & 29.04 & 7 & 19.14 & 12 & 8.00 \\
3 & 24.88 & 8 & 17.79 & 13 & 5.95 \\
4 & 22.18 & 9 & 17.62 & 14 & 8.00 \\
5 & 20.01 & 10 & 15.80 & 15 & 10.20 \\
& & & & 16 & 13.10 \\
\end{tabular}




\section{Discussion}

In this study, we investigated the oxidation of an oil rich in DHA and compared these results with data obtained in a previous study on linoleic acid oxidation in lactating women.

DHASCO is a refined single-cell triglyceride oil highly enriched in DHA that is produced by the microalgal strain MK 8805 [7]. Due to positional preference of DHA for sn-1 and sn-3, it is more similar to mammal than to fish oil. It is used as a dietary supplement to elevate the levels of DHA in conventional foods, especially in infant formulas [7, 8]. DHASCO labeled with ${ }^{13} \mathrm{C}$, a safe nonradioactive isotope that causes no radiation risk to mother or infant $[4,9,10]$, was used to measure fatty acid oxidation. Breath tests using stable isotopic labeled substrates are generally considered as safe and noninvasive tests to measure in vivo substrate oxidation [6, 11-13].

The baseline ${ }^{13} \mathrm{C}$ content in breath $\mathrm{CO}_{2}$ of mothers from the combined group was 1.0838 atom percent (1.0837-1.0839; median and IQR) and achieved peak ${ }^{13} \mathrm{C}$ enrichment of 1.1051 atom percent $(1.1027-1.1082)$ which represents $<2 \%$ enrichment over the baseline. The baseline ${ }^{13} \mathrm{C}$ content in breath $\mathrm{CO}_{2}$ measured in our study is slightly lower than the natural average ${ }^{13} \mathrm{C}$ abundance reported in Europeans (1.088) [14]. This is a reflection of the local Bavarian diet, with little intake of maize and cane sugar, but high in proportions of potato, cabbage, rice, and beet sugar, as well as the overnight fasting.

Our results show no apparent difference in the kinetics and the cumulative oxidation rate between the groups of women that were supplemented or not supplemented with DHASCO over a period of 14 days. The direct measurement of DHA oxidation was not intended in this study. This would have only been possible using a pure DHA tracer, instead of a mixture of different fatty acids.

We combined the results of the DHA-supplemented and the placebo groups and compared the oxidation of a single oral dose of ${ }^{13} \mathrm{C}$-DHASCO with the results of the ${ }^{13} \mathrm{C}$-linoleic acid oxidation obtained in a previous study [1]. Time points of sampling exhaled air and the measurement of ${ }^{13} \mathrm{C}$ enrichment of breath $\mathrm{CO}_{2}$ were performed in the same way and using the same instruments as in the current study.

Earlier maximum ${ }^{13} \mathrm{C}$ enrichment in breath $\mathrm{CO}_{2}(\mathrm{DOB})$ in the combined group versus the linoleic acid group (1.0 vs. 3.5; median) reflects the faster oxidation rate of the DHASCO tracer. Different kinetics of the oxidation of the two tracers can also be seen from the data of the PDR/h (fig. 1) and the cumulative recovery of the tracer in breath (fig. 3).

The oxidation rate of DHASCO tracer versus linoleic acid was faster, especially during the first $4 \mathrm{~h}$ after its ingestion. The ${ }^{13} \mathrm{C}$-labeled DHASCO tracer is a triglyceride-oil mixture that contains twelve different fatty acids, with the main components being lauric $(\mathrm{C} 12: 0)$, myristic (C14:0), and palmitic acid (C16:0) and DHA (C22:6n-3) which represent 84.2$97.5 \mathrm{w} \%$ of all the fatty acids (table 1 ). From the oxidation data alone, it is difficult to speculate which fatty acids are the ones with faster oxidation in DHASCO as compared with linoleic acid. Cumulative ${ }^{13} \mathrm{C}$ enrichments of single fatty acids at $48 \mathrm{~h}$ in human milk of mothers from the combined DHASCO group were severalfold higher for $\mathrm{C} 16: 0, \mathrm{C} 16: 1 \mathrm{n}-7$, C18:1n-9, and C22:6n-3 than for of C14:0 [unpubl. data]. This could be explained by a greater rate of $\mathrm{C} 14: 0$ oxidation in comparison with other mono- and polyunsaturated fatty acids contained in DHASCO. This preservation from oxidation is in agreement with the results of a study performed by Metges and 
Wolfram [15] who found greater and more rapid oxidation of trioctanoate as compared with trioleate after oral and parenteral administration in healthy adult volunteers.

It is likely that the faster oxidation rate of DHASCO, as compared to linoleic acid, is due to a quicker absorption and oxidation of shorter-chain saturated fatty acids (C8:0, $\mathrm{C} 10: 0, \mathrm{C} 12: 0$, and $\mathrm{C} 14: 0)$ contained in DHASCO. The cumulative oxidation of DHASCO is about $15 \%$ of the dose at $48 \mathrm{~h}$ after ingestion. This value is comparable to values obtained in other studies measuring fatty acid oxidation. Although there were differences in the kinetics of oxidation between the DHASCO group and the linoleic acid group, the cumulative oxidation 1 and 2 days after tracer application did not differ.

\section{Acknowledgements}

This study was supported in part by the Deutsche Forschungsgemeinschaft, Bonn, Germany (Ko 912/52), and Martek Biosciences, Columbia, Md., USA. Natasa Fidler was the recipient of a scholarship from Deutscher Akademischer Austauschdienst, Bonn.

\section{References}

1 Demmelmair $H$, Baumheuer $M$ Koletzko B, Dokoupil K, Kratl G: Metabolism of $\mathrm{U}^{13} \mathrm{C}$-labeled linoleic acid in lactating women. J Lipid Res 1998;39:1389-1396.

2 Hachey DL, Thomas MR, Emken EA, Garza C, Brown-Booth L, Adolf RO, Klein PD: Human lactation: Maternal transfer of dietary triglycerides labeled with stable isotopes. $\mathbf{J}$ Lipid Res 1987;28:1185-1192.

3 Martin JC, Bougnoux P, Fignon A, Theret V, Antonie JM, Lamisse F, Couet $C$ : Dependence of human milk essential fatty acids on adipose stores during lactation. Am J Clin Nutr 1993;58:653-659.

4 Koletzko B, Sauerwald T, Demmelmair H: Safety of stable isotope use. Eur J Pediatr 1997;156(suppl 1):1217.

5 Koletzko B, Demmelmair H, Hartl W, Kindermann A, Koletzko S, Sauerwald T, Szitanyi P: The use of stable isotope techniques for nutritional and metabolic research in paediatrics. Early Hum Dev 1998; 53(supl):77-97.
6 Rating D, Langhans CD: Breath tests: Concepts, applications and limitations. Eur J Pediatr 1997; 156(suppl 1):18-23.

7 Kyle DJ, Sicotte VJ, Singer JJ, Reeb SE: Bioproduction of docosahexaenoic acid (DHA) by microalgae; in Kyle DJ, Ratledge C (eds): Industrial Applications of Single Cell Oils. Champaign, American Oil Chemists' Society, 1992, pp 287-300.

8 Boswell K, Koskelo EK, Carl L, Glaza S, Hensen DJ, Williams KD, Kyle DJ: Preclinical evaluation of single-cell oils that are highly enriched with arachidonic acid and docosahexaenoic acid. Food Chem Toxicol 1996;34:585-593.

9 Klein PD, Klein ER: Stable isotopes: Origins and safety. J Clin Pharmacol 1986;26:378-382.

10 Jones PJH, Leatherdale ST: Stable isotopes in clinical research: Safety reaffirmed. Clin Sci (Colch) 1991; 80:277-280.
11 Heiling VJ, Miles JM, Jensen MD: How valid are isotopic measurements of fatty acid oxidation? Am J Physiol 1991;261:E572-E577.

12 Schoeller DA, Schneider JF, Solomons NW, Watkins JB, Klein PD: Clinical diagnosis with the stable isotope ${ }^{13} \mathrm{C}$ in $\mathrm{CO}_{2}$ breath tests: Methodology and fundamental considerations. J Lab Clin Med 1997; 90:412-421.

13 Demmelmair H, Sauerwald T, Koletzko B, Richter T: New insights into lipid and fatty acid metabolism via stable isotopes. Eur J Pediatr 1997;156(suppl 1):70-74.

14 Krumbiegel P: Stable Isotope Pharmaceuticals for Clinical Research and Diagnosis. Jena, Fischer, 1991, pp 70-72.

15 Metges CC, Wolfram G: Mediumand long-chain triglycerides labeled with ${ }^{13} \mathrm{C}$ : A comparison of oxidation after oral or parenteral administration in humans. J Nutr 1991;121: 31-36. 